\title{
An Analysis of the Pros and Cons of the Delayed Retirement Age in China
}

\author{
Ziyun Ren \\ North China Electric Power University \\ Beijing, China 102206
}

\begin{abstract}
As the aging problem is becoming more and more prominent today, whether to postpone the retirement age has been the focus of the public. Retirement is related to the vital interests of every worker. In this paper, combined with the status quo at home and abroad, according to China's national conditions, advantages and disadvantages of the retirement age delay analysis, delay the retirement age cannot stride in the short term, but not in one step, and step by step, considering various factors, formulate progressive retirement policy.
\end{abstract}

Keywords-delayed retirement; public policy; human resources; advantages and disadvantages analysis

\section{INTRODUCTION}

Delaying retirement refers to the gradual improvement of the retirement age system with the consideration of the change of population structure and employment situation in China

In recent years, with the continuous improvement of human living standards and the improvement of medical and health conditions, the life expectancy of population has been lengthened. Aging of population has gradually become a worldwide trend of development. For a country with a large population base in China, the nation's old-age security is facing a severe test. It is one of the important reform decisions put forward by the party in the third Plenary
Session of the 18th CPC Central Committee to study and formulate a gradual and delayed retirement age policy. Delays in the retirement age will inevitably have both advantages and disadvantages. It is indeed worth pondering over how to satisfy the interests of the majority in the trend of extending retirement age.

\section{THE BENEFICIAL EFFECTS OF THE DELAYED RETIREMENT AGE}

\section{A. Delay in Retirement Age to Meet the Needs of Aging}

In July 2012, the human resources development report (20112012) showed that the overall average retirement age for urban population in China is 56.1 years. In China, people aged 60 and over account for only $26.9 \%$ of the poor health. Therefore, the retirement age of China is relatively low, the utilization rate of the young is relatively low, and the development is insufficient, resulting in the waste of human resources.

According to experts from the research institutions, the elderly population will reach 255 million by 2020, 400 million in 2033 and 483 million in 2050 in "Fig. 1". Therefore, the delay of retirement age is the need to adapt to the growth of the population life expectancy, and it is also an inevitable choice to cope with the aging of the population.

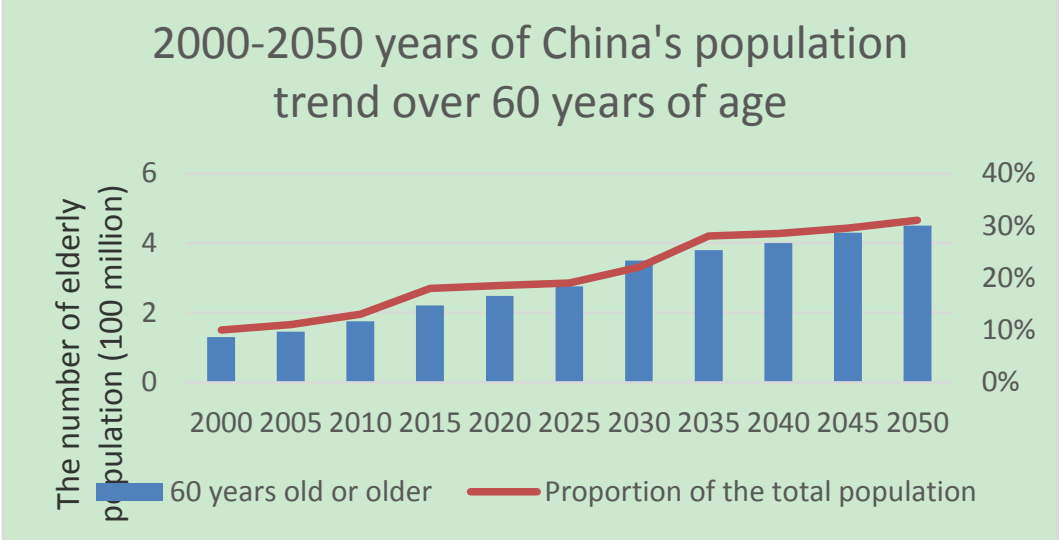

Fig. 1. 2000-2050 years of China's population trend over 60 years of age. 


\section{B. The Delay of Retirement Age Conforms to the Trend of Internationalization}

In recent years, most countries have raised their legal retirement age or planned to rise their retirement age. For example, the retirement age of the US will receive a full pension from 65 years to 67 years old. The age of pensioners in Korea will be adjusted from 60 to 61 in 2013, and it will increase to 65 in 2033. The general retirement age in China was set up in the 70 s of last century. The retirement age of employees is 60 years old, and the number of female workers is 50 years old. The number of female cadres is 55 years old as shown in "Table I". With the development of the times, the situation of supply and demand of labor is changing, and it is an inevitable trend to delay the retirement age.

TABLE I. COMPARISON OF PENSION INSURANCE SYSTEM IN SOME COUNTRIES

\begin{tabular}{|c|c|c|c|c|c|c|}
\hline \multirow{2}{*}{ Country } & \multirow{2}{*}{ Statutory time of payment } & \multicolumn{2}{|c|}{ Legal retirement age } & \multicolumn{2}{|c|}{ Life expectancy per capita } & \multirow{2}{*}{ Elastic retirement and Pensions } \\
\hline & & Male & female & Male & female & \\
\hline U.S.A & About 10 years & $65-67$ & $65-67$ & 76.2 & 81.3 & $\begin{array}{l}\text { Allow elastic retirement. The oldest } \\
\text { pensionable age is } 62 \text { years old, but } \\
\text { only a certain proportion can be } \\
\text { obtained. }\end{array}$ \\
\hline $\begin{array}{l}\text { The Republic of } \\
\text { Korea }\end{array}$ & About 10 years & 61 & 61 & 76.6 & 83.2 & $\begin{array}{l}\text { The retirement age in } 2033 \text { was } \\
\text { extended to } 65 \text { years. }\end{array}$ \\
\hline Canada & About 10 years & $65-67$ & $65-67$ & 78.9 & 83.5 & Allow elastic retirement. \\
\hline Mexico & About 24 years & 65 & 65 & 74.8 & 79.6 & $\begin{array}{l}\text { Be allowed to retire early at the age } \\
\text { of } 60 \text {. }\end{array}$ \\
\hline Spain & $\begin{array}{l}\text { The minimum } 15 \text { years, } \\
\text { the future will be } \\
\text { extended to } 25 \text { years }\end{array}$ & 67 & 67 & 78.8 & 84.8 & $\begin{array}{l}\text { It is allowed to retire ahead of time, } \\
\text { take part of the pension, and } \\
\text { encourage the delay of retirement. }\end{array}$ \\
\hline
\end{tabular}

C. The Delay of Retirement Age Is Conducive to Improving the Utilization of Human Resources and Promoting Social and Economic Development

For the enterprise, the old employee represents experience and wealth, and the skillful and skilled experience can bring more income benefit to the enterprise. At the same time, the old employees teach young people with their own experience, save the cost of investment, invest more money in production, and promote social and economic development.

For individuals, the extension of retirement age directly increases the current income, and then promotes consumption, indirectly driving the development of enterprises, enabling enterprises to expand production and improve GDP, which is conducive to the development of market economy.

\section{The Delay of Retirement Age Will Help to Make up the Pension Deficit and Reduce the Financial Burden of the State}

The development process of old-age security in China compared to western developed countries late, the system is still not perfect, although in recent years has made a breakthrough achievement, but some problems still to be solved, such as the payment rate is low, the phenomenon of serious arrears payment, early retirement, China's endowment insurance is facing financial crisis. The easiest way to solve the pension gap is to delay the retirement age. Even if the number of contributions and contributions is increased, and the payment time is shortened, we should improve the balance of payments from two aspects of multiple incomes and less expenditure, to a certain extent, to reduce the pressure of fiscal expenditure and reduce the financial burden of the state.
E. The Delay of Retirement Age Is Conducive to Increasing Family Income and Reducing the Burden of Support for Young People

In terms of the general income situation, most people's wages are higher than those after retirement. Since the implementation of family planning policy in 70s, the family structure of "4-2-1" has gradually become the mainstream mode. In this context, a young couple needs to face the burden of at least four elderly people. In addition, our country's employment situation is severe and multiple burdens are added, which will have a series of adverse effects on family and social stability. The delay of retirement age, allowing the elderly to maintain their own stable income, is conducive to reducing the burden of the family.

\section{THE AdVERSE EFFECTS OF DELAYED RETIREMENT AGE}

\section{A. The Delayed Retirement Age Increases Employment Pressure in the Short Term}

In the current situation, the demographic dividend still exists. In recent years, the number of college graduates has increased dramatically in "Fig. 2", and the surplus rural labor force has also poured into the city. But the speed of economic growth is not enough to provide enough employment opportunities for the new labor force every year. Delayed retirement will lead to job squeeze again. The invisible competition between young generation and older generation will make young people become marginalized groups of employment and bring some impact on China's employment market. To some extent, it will lead to the loss of the vitality of the enterprise, limit the space for the younger generation, and is not conducive to the transformation and upgrading of the enterprise and the innovation and development. 


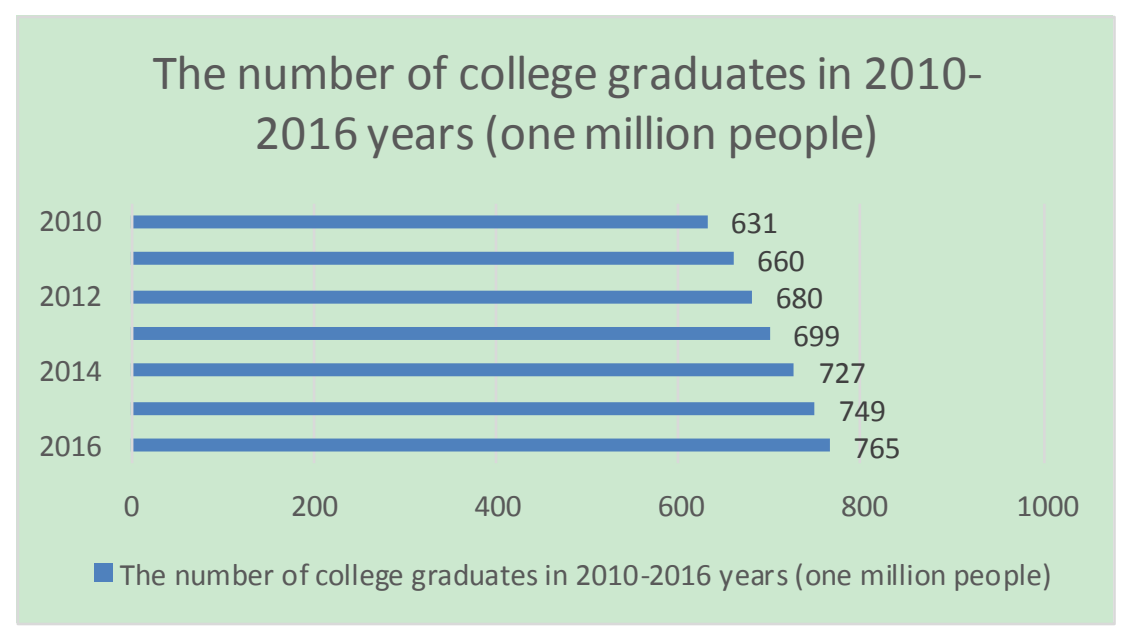

Fig. 2. The number of college graduates in 2010-2016 years.

B. The Delay of Retirement Age Aggravates the Life Pressure of the Disadvantaged Groups and Aggravates the Social Inequality

The survey found that for the problem of "attitude towards postponing retirement age", the percentage of the respondents was $21 \%$, the neutral attitude was $23 \%$, and the disapproval rate was $56 \%$ in "Fig. 3".

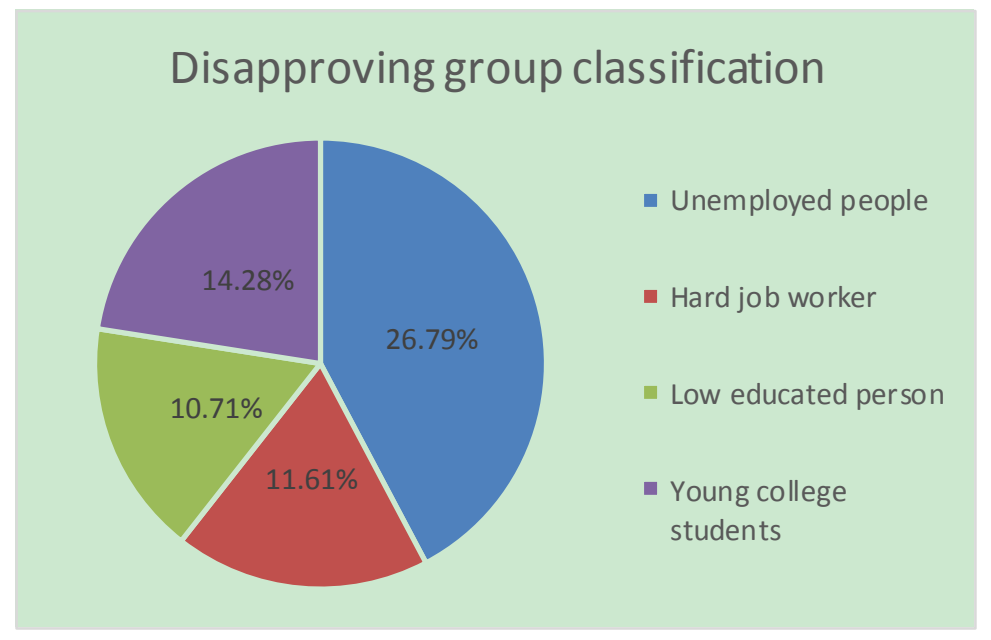

Fig. 3. Disapproving group classification.

Thus, the delay of retirement is not only a problem of pension, but also a matter of personal interests. With the extension of retreat is high wage and high welfare mental workers, civil servants and employees of monopoly enterprises, against the extension of retirement is in low wage low welfare position labor groups, laid-off workers, their income is limited, expect to reach the statutory retirement age of retirement pension. Therefore, the delay of retirement will lead to the weakening of the social status of different groups of identity, the unfairness of the middle and low income workers, and the social inequality.

\section{The Age of Delayed Retirement Detrimental to the Physical and Mental Health of the Elderly}

Although the life expectancy of our country has increased gradually in recent years, with the increase of people's age, the function of human body will fall correspondingly, and all kinds of health problems have followed. Older employees tend to feel more oppressive and suffer more stress when dealing with the same problem with young people. Over time, the double oppression of body and mind inevitably causes great health problems to them.

\section{The Delay of Retirement Age Creates a New Financial Burden}

The delay of retirement policy, while solving the pension gap, also brings new financial problems. With the increase of retirement age and living cost, the pension standard of retirees will increase. The characteristics of rigid growth of social security will inevitably lead to the increase of financial expenditure. In addition, the aggravation of the burden of pension insurance will lead to the decline of the market 
competitiveness of enterprises, and the support of the government to enterprises will also increase, which will also aggravate the financial burden to a certain extent.

\section{CONCLUSION}

Whether or not to postpone retirement age is closely related to financial status, aging degree and industrial development and so on. China should take full account of its national conditions when drawing lessons from other countries' retirement plans. At the same time, we need to make preparations for raising the retirement age reasonably, especially the starting time. We should consider the fund, the dependency ratio of the system, the relevant laws and the acceptance of the society. First of all, we should insist on the difference of the policy, and cannot put all the people into the extended range. Specifically, different retirement schemes can be divided into different industries or industries, especially the related measures should be refined to civil servants and public servants of state-owned enterprises. Secondly, we can realize the independent mechanism outside the system, improve the old-age security and give appropriate financial subsidies. Moreover, in the delay of retirement, we should make great efforts to support independent entrepreneurship, develop private enterprises and create jobs by themselves. Finally, the process of making and implementing the policy is transparent and fair, guiding the people to understand the policy correctly and slowly and steadily through the flexible system.

We should achieve resilient retirement, rigid government support, equal retirement age for men and women, rationalization of social insurance contributions for postponed retirees, non-privileged delaying retirement age and social resources and other resources coordination. Only by implementing this policy can we have an effect on the current situation of population aging in China, and alleviate the contradiction among China's labor employment, population policy and social security.

\section{REFERENCES}

[1] Chen Xiaoyan, Peng Wenzhuo. Pay attention to listening to the voice of workers in high intensity and hard job [N]. workers daily, 2016-0312

[2] Korean dream. Analysis of the extension of retirement age in China from the perspective of public policy [J]. reform and opening, 2016 (06): 88-92.

[3] The problem of the retirement age in China and the necessity of the implementation of delayed retirement $[\mathrm{J}]$. Social security research, 2010 (2): 32-38.

[4] Dai Weidong, Li Kai. A review of the study on the delay of retirement age $[\mathrm{J}]$. Journal of Jiangsu University (SOCIAL SCIENCE), 2015 (02). 